\title{
Hr. v. Köller og Fyrst Imeritinski
}

I.

Dersom Nogen spurgte mig, for hvis Skyld vi bør gøre Alt hrad vi formaar for at bevare dansk Nationalitet og dansk Sprog i Nordslesvig, saa vilde jeg svare: Allerførst for vor egen Skyld. Det, at der er en Strækning paa Jorden, i vor umiddelbare Nærhed, hvor vor Nationalitet forsøges udvisket, hvor vort Sprog fortrænges og vore Farver forbydes, det holder, naar vi bruger denne Kendsgerning rigtigt, Vrede og Modstandskraft oppe hosos. Vi lider just ikke under for stor Selvfølelse som Nation. Det, at vort Flag trædes under Fødder og at Dankkheden faar Mundkurv paa, det vækker, hvis vi duer noget, den nationale Selvfølelse hos os.

Dernæst bør vi selvfølgelig gøre hvad vi kan for Nordslesvigernes Skyld. For at de i Bevidstheden om vor virksomme Deltagelse kan holde Humøret oppe. Nu gør ganske vist Prøjserne paa deres Side, hvad de formaar for holde Humøret oppe hos dem. Men det lykkes ikke altid. Det gaar med Prøjserne som med Skomageren $\mathbf{i}$ Historien, der vilde have, hans Børn skulde være glade. Da de ikke var glade nok, saa bankede han dem for at de skulde blive glade. Og han undredes højligt over; at jo mere han bankede dem, des mere misfornøjede var de. 
Vi maa bruge andre Midler til at støtte deres Humør. De maa have Fglelsen af, at vi ikke har sluppet dem i vore Tanker, men er med dem. Det er jo altid behageligt at vide sig elsket og fulgt med Deltagelse. De bør vide, at vi er med dem, ikke blot hjerteligt men forstandigt.

Endelig bør vi om end ganske stilfærdigt vise Nordslesvigerne vor Medfølelse, for Prøjsernes, for Tyskernes egen Skyld. Det vil være usigelig gavnligt for Tyskerne selv at mqde hos et ganske lille Folk en Modstand, som de aldeles ikke kan overvinde. Det vil helbrede dem for den Smule Selvgodhed eller Indbildskhed, som unegtelig vansirer or misklæder dette saa velbegavede og overordenlig dygtige Folk. Det vil lære dem forgget Respekt for aandelige Magter. Allerede af ren og uegennyttig Kærlighed til Prøjsen bør vi da gøre det Arbejdet med at fortyske Nordslesvig surt. Engang i en bedre Frentid vil Prøjserne selv takke os for det.

\section{II.}

Vi betragter i Regelen den Del af Polen, der staar under russisk Herredomme, som Typen paa et undertrylkt Land. Man kan ogsaa uden Overanstrengelse af Indbildningskraften tienke kig mere lykkeligt stillede Folk end de russiske Polakker. Ikke des mindre er de i mange Maader heldigere stillede end de danske Nordslesvigere under det tyske Styre. I det sidste Aar er Polakkernes Lod i Rusland blevet bedre, de Danskes Lod i Prøjsen blevet bestandig værre.

At Polakkernes Stilling i russisk Polen i den allersidste Tid er bleven noget mindre trykket, skyldes udelukkende en enkelt Mand, Kongeriget Polens for ikke 
meget lang Tid siden udnævnte Generalguvernør, Fyrst Imeritinski. Under General Gurkos haarde og forhadte Herredømme var Polakkerne ikke blot som endnu berøvedeal borgerlig og politisk Frihed, men Kampen imod deres Sprog rastede intet Øjeblik. Efter Grev Sjuvalofs korte Mellemregering blev 1897 Fyrst Imeritinski ansat og vakte strax Forhaabninger i Polen ved at tillade Oprettelsen af Nationaldigteren Mickiewicz's Statue i Varsjov. Denne Tilladelse var mærkværdig; thi Mickiewicz havde været den bitreste Fjende af russisk Overhøjhed over Polen, og hans Værker vrimler af Angreb paa Undertrykkerne. Fyrstens Handlinger pegede inidlertid i forskellige Retninger. Dels knyttede han Betingelser til den givne Tilladelse. Der maatte ikke findes nogen Bifigur, ikke nogen Kvindeskikkelse, paa Mindesmærket; thi en saadan Skikkelse vilde blive opfattet som Polen. Det maatte afsiøres i al Stilhed en tidlig Morgenstund uden Sang og Klang og Tale. Ogsaa i andre Tilfælde optraadte Fyrsten meget strengt, saa man var uklar over hans Karakter og Stræben. Det er først $i$ den sidste Halvdel af Aaret 1899, at hans Regreringsgrundsøtninger blev røbede ved en Offenliggørelse af enestaaende Art.

Et Aar efter sin Udnævnelse, 18. Januar 1898, rettede Fyrsten til Kejser Nikolaj en Indberetning om den russiske Politiks Resultater og Opgaver i russisk Polen. Denne Skrivelse blev i St. Petersborg drøftet i Statsraadet i to lange Møder 10. og 17. Februar 1898, og udforligt blev alle her faldne Udtalelser forte til Protokols. Men desuden indgav Statsraadets Cancelli en udfyldende Mælding til Kejseren, hvori alle Stridsspunkter blev fremhævede og underkastede hans Afgørelse. 
Paa en Maade, der trods Masse-Fængslinger i Varsjov ng St. Petersborg endnu er ganske uopklaret, blev saavel Imeritinskis Indberetning som hele Gengivelsen af Statsraadsmøderne, Cancelliets Meddelelse og Kejserens Randgloser til alle de ham forelagte Aktstykker ranede og offenliggjorte af de polske Socialisters Forening i London. Den første Udgave blev hurtigt udsolgt i England, den anden udkom i Krakov, begge i det polske Sprog. Derefter udgaves det russiske Grundskrift. Der er vel at mærke ikke fra den russiske Regerings Side gjort nogetsomhelst Forsøg paa at nægte disse Dokumenters Panlidelighed, og de har givet Europa et hidtil ukendt Indblik i den russiske Styrelses Maskineri.

De viste først og fremmest, hvilken fremragende og oplyst Statsmand Polens Generalguvernør er. De gav En dernæst et fyldigt Indtryk af, hvilken overbevist Tilhænger den græsk-ortodokse Kirke har i Kejseren af Rusland og af hvor rigtigt han finder det, endog ved Anvendelse af Tvang at sikre denne Kirkes Herredømme. Til Udtalelser af Imeritinski, der tilraadede at vise nogen Taalsomhed mod den romerske Katolicisme i Polen, har Kejseren egenhændigt tilføjet: Den Anskuelse deler jeg ikke. - Man kan overhovedet i Almindelighed sige: Skønt Imeritinski taler som Russer, der aldrig slipper den russiske Stats Tarv af Syne, optræder han dog som Talsmand for en klog Humanitet, og omvendt: Skønt Kejseren taler som rettroende Kristen, kommer hans polske Undersaatters personlige eller aandelige Velvære end ikke i Betragtning for ham i Sammenligning med det ene Maal, han har for Øje: den russiske Stats overvældende Magt.

Generalguvernøren gaar ud fra den Grundsætning, 
at det er unuligt, ved materielle Velgerninger alene at vinde et Folks Hjerte. Bondestanden har tidligere været Grundvolden for al russisk Magt i Landet; thi Bønderne var længe Czaren taknemmelige, fordi han efter Underkuelsen af det Oprør, der udbrød 1863, ophævede Livegenskabet $0 \mathrm{~g}$ fordelte adeligt Gods til de fattige Landbrugere. Før Reformen 1864 var 1,300,000 Bønder uden Land. Dengang blev Jord fordelt til 1,100,000 jordlsse. Men siden da har Bøndernes Stilling paany forværret sig saaledes, at omtrent det samme Antal ei uden Jord nu som i 1863. En Fjerdedel af alle russisk Polens Bonder ejer ingen Jord. Deraf en naturlig Utilfredshed. Men hertil kommer, at Standskløften mellem Adelen og Bønderne nu er i Færd med at udfyldes. Dels har der dannet sigr en Middelstand, dels gaar de højere Stænders Bestræbelsel gennemgaatende ud paa, gennem Oplysning af Masserne at naa til et uafhængigt Polen. Man har efterhacuden udgivet en Folkeliteratur og oprettet Folketeatre, ja de Højtdannede viser Bønderne om i Varsjovs Museer.

Saaledes foler efterhaanden den hele Befolkning ganske ens, og dens Følemaade er i høj Grad fjendsk mod Rusland.

En Hovedskyld for Modstanden bærer efter Fyrstens Fremstilling den romersk katolske Gejstlighed, der ikke er at bevære til nogensomhelst Form af Underkastelse or som hverken kan bøjes eller knækkes. Det har ikke nyttet at fordrive den fra Skolerne og tage Religionsundervisningen ud af dens Haand; dette har kun ophidset den yderligere mod alt Russisk. At den græask-ortorlokse Lære udøver saa liden Tiltrækning beroer efter Fyrstens Opfattelse for en Del paa dens Kirkers Simpelhed og Fattigdom 
i Sammenligning med de romerske Kirkers Rigdom og Pragt. Han foreslaar derfor Bygningen af pragtfulde russiske Kirker som nødvendigt Lokkemiddel. Kejseren istemmer her med Styrke og fordrer hurtig Fuldførelse af den uhyre russiske Kirke, der saa længe har været under Bygning i Varsjov og som efter Planen skal koste 2,700,000 Rubler (c. 7,700,000 Kroner).

Med andre Ord: Generalguvernøren viser, at den hidtil fulgte Fremgangsmaade ikke har ført til nogetsonhelst ønskeligt Resultat, og med anerkendelsesværdig Aabenhed giver han den russiske Embedsstand i Polen en Hovedskyld derfor. Han betegner den som halvdannet, indskrænket, slet opdraget, doven og vulgær, siger, at den tror sig alting tilladt efter det russiske Ordsprog: Over Sejrherren gives der ingen Dommer. Med ikke mindre anerkendelsesværdig Aabenbed fremhæver han de undertrykte Polakkers Fortrin.

Hvor han taler om Bondestandens Fattigdom, gor han gældende, at den ikke desmindre er glimrende stillet i Sammenligning med den russiske i hvilkensomhelst Del af Riget. Der er i Polen aldrig Hungersnod, medens i det Indre Hungersnøden uafbrudt er tilstede. Sparepengene vokser. Der er insen Gæld par Landbruget. Han sætter sig da ogsaa imod de andre Ministres Forslay om tvangsvis at overføre en halvanden Million af Bønderne til det nordøstlige Rusland (langs Banelinjen Perm-Kotljas), et Forslag, der minder om den fjerne Oldtids Assyrers og Babylonieres Fremgangsmaade overfor erobrede Folk.

Og som Fyrsten roser Bøndernes Flid, saaledes fremhever han de arbejdende Klassers overordenlige Iver og 
Samvittighedsfuldhed og „den for det hele polske Folk ejendommelige udmærkede Smag“.

Hvad Skolerne angaar, hævder Generalguvernøren, at de fuldstændigt maa være i Statsmagtens Hænder (Kejserens Randglose: Selvfølgelig!) Men Hovedmanglen ved dem er for ham den, at der kun paa Russisk undervises i Polsk.

Allerede General Gurko skrev i 1890: „I Statsskolernebehandler man det polske Barn ikke blot ikke kærligt, men ligefrem fjendtligt; man bebrejder det dets polske Byrd, fornærmer dets Nationalfølelse, udtaler sig med Foragt om dets Religion og giver dets Modersmaal Plads efter de fremmede Sprog, efter Fransk og Tysk." Allerede Gurko skrev: „Der maa opstaa en ny Statsskole i Polen, som ikke øser sin Kraft af Elevernes og deres Forældres Værgeløshed.“ Imeritinski foreslaar derfor, at det russiske Undervisningssprog $i$ de polske Timer skal erstattes af Polsk og at der istedenfor to Timer om Ugen skal sættes fem eller seks, og han hævidede i Statsraadet dette overfor Folkeoplysnings-Ministeren Bogóljepov, der i Stil med den prøjsiske Synsmaade for Nordslesvigs Vedkommende mente, det var bedre, helt at ophæve Undervisningen i Polsk og overlade den til Hjemmene.

For ikke mange Uger siden er endelig Imeritinskis Plan trængt igennen. Polsk Sprogundervisning er nu indført som paabudt i samtlige lærde Skoler, Realskoler og andre lignende Læreanstalter; det ugenlige Timetal deri er fordoblet, og saaledes er da nu i russisk Polens bedre Skoler det polske Sprngs Stilling i høj Grad forbedret. Samtidigt er i Almueskolerne Undervisningen i Polsk steget fra tre ugenlige Timer til seks. Paa Polsk undervises nu i to Fag, Polsk og Religion; paa Russisk i to 
Fag, Russisk og Regning, og saaledes er da Sprogenes Ligestilling helt gennemført. Ikke i 36 Aar har Polsk indtaget en saadan Plads i russisk Polens Skoler.

\section{$1 I I$.}

Naar man, som sagt, vil nævne et særlig ulykkeligt Folk, saa næuner man Polakkerne, og især dem, der er under Rusland. Men det vil ses, at den russiske Regering for Øjeblikket $i$ sit Forloold til dem er langt humanere og mildere end den projsiske Regering i Slesvig er overfor de Dansktalende. Russerne indscr, at materielle Velgerninger alene ikke kan vinde et Folk; de har dog givet 1,100,000 livegne Bønder Frihed og Jord. Tyskerne har Intet gjort for den danske Bondestand i Nordslesvig, har kun hæmmet dens Fremskridt og sat den tilbage, betydeligt tilbage for Kongerigets.

Den russiske Generalguvernør priste de polske Bønders Fortrin for de russiske, havde kun Lovord for Arbejdernes Dygtighed og for det polske Folks Smag; han dadlede $i$ stærke Udtryk de russiske Embedsmænds Færd. - Kunde det tonkes, at $\mathrm{Hr}$. v. Köller i nok saa fortrolig en Skrivelse udtalte sig paa samme Maade om tyske Embedsmænds Fremfærd i Nordslesvig? Og dog kunde han visselig gøre det uden at lyve. Kunde det tænkes, at Hr. v. Köller med saadan Varme vilde give sig til at prise danske Bønder, dansk Haandværk og dansk Intelligens? Og dog kunde han maaske gøre det uden at fare med nogen Usandhed.

Hvor højt vort Landbrug og Mejerivæsen staar over det tyske, er alment anerkendt. Og vi har i mange Maader bedre Smag, f. Eks. renere Kunstsans end Prøjserne, der ikke er det i kunstnerisk Henseende ypperst udrustede af de germanske 
Folk. Vi er overfor dem tilnærmelsesvis stillede som Hollænderne. Disse var altid gode Sømænd og viste sig som bekendt i deres kunstneriske Blomstringstid de tyske Malere langt overlegne. Vor Kunst taaler vel ingen Summenligning med Hollands fra dets store Tid. Men med vore Dages Hollændere kan vi omtrent maale os kunstnerisk, og vi overgaar dem vistnok literært. Vi staar da aandeligt overfor Prøjserne omtrent som det hullandske Folk.

Sammenligner vi Undervisningsvæsenet $\mathrm{i}$ den polske Del af Rusland og i Nordslesvig, saa viser det sig, hvor langt bedre Polakkernes Stilling er. De undervises halvt paa Polsk, de faar Undervisning i l'olsk, og det endia ikke paa russisk, men i deres Modersmaal.

$\mathrm{Nu}$ véd Alle og Enhver; at om Undervisning i dansk Sprog er der i Nordslesvig overhovedet ikke Tale. Kun i Religion skulde der $\mathrm{i}$ de danske Egne gives to ugenlige Undervisningstimer paa Dansk; men end ikke dette overholdes. De indvandrede Embedsmand, et Par Hjemmetyskere og de mange danske Undersatater, der lever i stadig Frygt for Udvisning, underskriver dels frivilligt, dels nodtvungent Andragender om, at endog disse to stakkels 'Timer naa blive sløjfede, og Falgen er, at de for Tiden er sløjfede næiten overalt.

Er saaledes Guvernøien i russisk l'olen humanere sindet overfor den Folkestamme, der ikke er hans egen, end Hr. v. Köller er i Nordslesvig, saa er overhovedet Polakkernes Stilling gunstigere end de Danskes. De Undertrykte iblandt dem har altid et Tilhold hos Millioner Polakker i Grænselandet Galizien, der nyder fuldt Selvstyre. Og blot de Undertryktes Antal gør Trykket mindre tungt. Alene i russisk Polen er der 15 Millioner Polakker, 
og de har Byer som Varsjov med 800,000 Indbyggere. Vi har Haderslev med 8000 Indbyggere og Aabenraa med 6000. Dersom de Danske under tysk Regimente var femten Millioner i Tal, havde det ingen Nød. $\mathrm{Nu}$ er de hundrede Gange færre.

Saa har endelig Polakkerne fremfor de annekterede Danske det umaadelige Fortrin, at de er af en anden Religion end deres Herrer. Det russiske Vælde møder $i$ Romerkirkens Vælde en næsten jævnbyrdig Magt, et Bolværk, som vanskeligt rokkes. Vor Stilling har det ugunstige Element, at de Undertryktes Religion er den samme som Undertrykkernes, ja at de Danske endog har faaet Protestantismen fra Tyskland, i dens lutherske Form, som hverken forekommer i England eller Holland eller Schweiz. 1 den i de slesvigske Skoler indførte Vaterländisches Lesebuch forherliges derfor Reformationen som en særlig tysk Daad. Og det hedder: Martin Luther har kædet Slesvig til Tyskland.

Des mærkeligere er det, at end ikke Religionsfrihed har man fra tysk Side villet indrømme paa nordslesvigsk Grund, og det skønt den prøjsiske Grundlov tilsiger fri Religionsøvelse og Forsamlingsfrihed. Under et intetsigende Paaskud har man lukket to danske Kirker. I 1896 byggede en dansk Frimenighed, der havde hestaaet $i$ tyve Aar, i Bovlund en lille Kirke. Man benyttede sig da af en gammel Bestemmelse fra den danske Tid, der skulde sikre Menighederne, at Kirkerne var forsvarligt byggede og ikke kunde styrte ned over Hovederne paa dem. Bestemmelsen lød paa, at enhver Kirke skulde synes før den toges i Brug, og forbød at bruge Kirken uden ministeriel Tilladelse. I over tre Aar er Tilladelsen udebleven, 
og Kirken i Bovlund forbleven lukket. Samme Fremgangsmaade er bleven anvendt overfor en Kirke i Haderslev. Hvor meget humanere tænker ikke Fyrst Imeritinski, der ikke lukker de katholske Kirker, men kun ved smukke Kirkebygninger vil kappes med deres Pragt!

Det gjælder visselig ikke for os om at bruge store Ord, mindst om at bruge Ukvemsord mod Tyskheden. Ikke ét ondt Ord bør fra dansk Side falde om det meget Værdifulde i Tyskland. Ulykken er, at den Side, Tyskland vender ud imod os, er den embedsstive og hensynsløse prøjsiske Bureaukrat- og Gendarm-Side, som ikke er vindende.

Der staar i en gammel dansk Roman om en Løjtnant, der ikke fremstilles som særdeles meget værd, at han ikle desmindre var saa elskværdig, at det forekom En, som om Naturen med usynlig Skrift havde skrevet paa hans Pande: „Jeg vil, at Alle skal elske denne slemme Knægt." De Ord har ingen læst paa Projserens Pande. Det fordærvede Frankrig har haft Tidsrum i dets Historie, hvor det gjorde dette Indtryk, Prøjsen aldrig. Allerede af den Grund, at Prøjseren ikke er nogen saadan slem Knægt, men alvorlig, sædelig, stiv og streng. Han gør ikke engang selv Krav paa at være elskværdig.

\section{IV.}

Af de tre Folk, som delvis befinder sig under det tyske Riges Herredømme, er de Danske som de faatalligste og som de ved Sprog og Religion med Prøjserne nærmest beslæutede, den uden Sammenligning ugunstigst stillede Stamme. Derved er selvfølgelig Intet at gøre. Vi maa deri se en Opfordring mere til haardnakket Modstand mod at lade os oversvomme. Thi formaar vi ikke at he- 
vare vort Sprog hinsides Grænsen, sar er det naturligvis kun et Tidsspørgsmaal, naar det ogsaa paa denne Side af Grænsen trænges tilbage. Men Sprogets Fremtid rig vor Nationalitets Fremtid falder ganske og aldeles sammen.

Vort Sprog er truet Samtidig med at Prøjserne i Nordslesvig uddrev Danskheden af Stat, Kirke og offenlige Hverv, bemægtigede de sig fuldstændig Skolerne. I Skolen skulde Barnet opdrages og afrettes til rettroende Prøjser.

I det tyske Sanghefte for de slesvigske Skoler er i broget Mængde optaget Salmer, Folkeviser, nye Sange af krigerisk, idyllisk og patriotisk Indhold. Men paa de uskyldige Sange laggges faktisk af Skole-Inspektørerne slet ingen Væut. Der er en Del af disse Sange, som Børnene skal kunne udenad, og det er de krabate Sange: Heil dir im Siegerkranz, Schleswig-Holstein meerumschlungen, Ich bin ein Preusse. Denne sidste Sang er navnlig lærerig, fordi den er særlig fuldstændiggjort til Bedste for de slesvigske Skoler. Det er den bekendte svulstige og sletskrevne Sang af en vis Schneider, der begynder:

Ich bin ein Preusse! Kennt Ihr meine Farben?

Die Fahne schwebt mir weiss und schwarz voran.

Dass für die Freiheit meine Väter starben, das deuten, merkt es!, meine Farben an.

Fr der nu Noget, for hvilket Prøjserne ikke plejer at dø, saa er det for Friheden. Den Frihed, her menes, er Befrielsen for Fremmedherredømmet, som den opnaaedes ved den saakaldte Frihedskrig mod Napoleon I, en Rejsning, der foretoges paa enevældige Fyrsters Befaling og som ikke havde nogensombelst indre Frihed hverken til Formaal eller til Falge. Man ser det bedst deraf, at 
Sangen nu bruges netop til Befæstelse af et Fremmedherredømme, som Kampmiddel mod Friheden for Tvangen.

Prøjsen har aldrig fort Krig for at bringe Frihed. Det har andre Idealer, værdifulde Idealer, men ikke dette. Det er da ikke ganske ærligt, at dette i Nationalsangen nævnes allerførst. Det er heller ikke om Frihed, der er Tale i den sidste Strofe, som er tilføjet til Bedste for de nordslesvigske Børn. Den siger: Vi, der siden Dybbøldagen er lænkede til Prøjsens Trone og Folk ved Blodets Baand, vi vil ikke se tilbage; vi vil se fremad med Tillid. Vi raaber det ud i den vide Verden: Ogsaa vi er Prøjsere, vi vil være Prøjsere. ${ }^{1}$ )

I alle de andre Sange prises Troskab mod Fortiden ऽ: Troskab mod Nationaliteten. Her alene anbefales det Modsatte, idet de Danske opfordres til ikke at se tilbage. Dernæst: Ved Blodets Baand plejer man at forstaa Slægtskabets, det nærmeste Slægtskabs Baand; man tænker paa det Blod, der rinder i Aarerne. Her bruges sofistisk Blodets Baand om det udgydte Blod, Blodet paa Jorden. Og med en meget slet Lignelse bedder det saa, at ved dette udøste Blod er Nordslesvigerne lænkede til Prøjsens Trone (først) og til dets Folk (sidst). Dette er maaske ikke noget at glædes ved, men det kan idetmindste som en Kendsgerning ikke modsiges. Ganske fornuftstridigt

1) Und wir, dic wir am Oat- und Nordseestrande als Wacht gestellt, gestählt von Wog' und Wind, wir, die seit Düppel durch des Blutes Bande an Preussens Thron und Volk gekettet sind, wir woll'n nicht rückwärts schauen, nein, vorwärts mit Vertrauen!

Wir rufens laut in alle Welt hinein : Auch wir sind Preussen, wollen Preussen sein! 
er det imillertid deraf at slutte til den frivillige Hengivenhed ng herefter lade Brrnene synge, ja raabe ud i den vide Yerden: Vi $\mu$ Prøjsere, vi vil vare Prøjsere. Thi det er netop det, de ilike vil, og det, de ikke kan tvinges til at ville.

I Vaterlïudisches Lrsebuch findes et Billede og en 'Tekst, der ofte har givet Anledning til pinlige Optrin i Skolerne. Der ses den ganle Kejser Wilhelm med Pikkellue $\mathrm{i}$ en uhyre Laurbarkrans, som hviler paa Kanoner, Geværer, Sabler og prøjsiske Ørnefaner. I T'eksten hedder det om 1864: „I det Aar bragte Kong Wilhelm Klarhed og Afgørelse i Slesvig-Holstens forviklede Forhold til Danmark. Modig hævidede han med Sværdet Hertugdømmernes Ret og udløste dem af den Forbindelse med en ikke-tysk Stat, der var bleven mere og mere utaalelig. Det var $i$ alt Væsenligt hans Fortjeneste, at disse skønne ng rige Provinser for altid blev tilbagegivne til Tyskland.“ Dertil et begejstret Digt Dybbaldayon af den ivrige Prøjser Th. Fontane.

I Bogens sidste Afdeling Slesvig-Holsten $i$ historiske. og gengrafiske Billeder, der vækker Børnenes Uvilje og som indledes med den gamle Oprørssang, fortælles det, at $\mathrm{i}$ det sjette Aarhundrede tilfaldt Jylland fremmede, danske Folkestammer, og Resterne af den angelske og jyske Befolkning antog Sejerherrernes Sprog - et Forsøg paa at lade der have været et ældre tysk Sprog før det danske i Slesvig, der ikke blot ingen historisk Hjemmel har, men gendrives af de Rune-Indskrifter; der er fundne paa slesvigsk Grund.

„Fxdrelandshistorien " fortælles saa til Danmarks Forsmadelse. Der dvæles i Prosa og Vers ved Valdemar 
Sejrs Nederlag; hans Sejre fortælles ikke. Man glæder sig over Brodermoderen Abels Nederlag mod Friserne; Grev Gerhard den Store forherliges; Niels Ebbesen beskæmmes som den, der snigmyrdede den syge Greve $\mathrm{i}$ hans Seng. Kong Hanses Nederlag ved Hemmingstedt, hvor Danebrog tabtes, berettes med Tilfredsstillelse, og med Stolthed og Jubel fortælles Ulykken ved Eckernførde. - En anden foreskreven Læsebog Deutscher Kinderfreund, der bruges flittigt, har ligeledes vidtløftige og stolte Skildringer af Nederlaget ved Eckernførde 1849 og Stormen paa Dybbøl Skanser 1864.

1 en Skolebog Erzählungen aus der deutschen Geschichte er, som allevegne, Slesvigholstenernes Frihedskamp, Slesvigholstens Befrielse vigtige Kapitler. Tiden imellem de to Krige fremstilles saadan: „De Danske holdt ikle deres Forpligtelser; de søgte at udstrække deres Nationalitet sønderpaa og optraadte især i Slesvig med grænseløs Vilkaarlighed. Alt hvad der var tysk blev forfulgt og plaget, og den, der vovede at gøre Modstand mod deres retløse Skalten og Valten, udsatte sig for den haardeste Straf." Byttede man Folkenavnene om og forandrede sønderpaa til nordpaa, lod dette sig maske anvende paa det Aar 1900.

Ethvert Barn skal eje Samlingen Bibelsprüche und Bibelabschnitte für die Volls- und Mittelschulen og nøjagtigt kunne oprense disse tyve tætte Sider Skriftsteder. De begynder meget passende: „Hvad hjalp det et Menneske, om han vandt den halve Verden, ifald han tog Skade paa sin Sjæl!“ - et Skriftsted, Prøjserne skulde lægge sig paa Hjerte.

En Mængde tyske Lærebøger og Læretraade er forfattede af en Hjemmetysker, en danskført Seminarielærer 
i Halerslev. Saaledes Beskrivelsen Stadt und Land. Deri hedder det paa Tysk: Hadersleben er en tysk By. Paa det nordre Torv staar et Mindesmærke for dem, der faldt i Krigen mod Danskerne 1848-1850, paa Sondertorvet en Statue af Kejser Wilhelm I“ . . . . . fyndige Beviser paa Byens Tyskhed. „Vi véd, at kíresen Hadersleben er en Del af Provinsen Slesvig-Holsten og denne en Provins af Kongeriget Prajsen. Kongen hedder Wilhelm II. Kongeriget Prajsen er en Del af Kejserriget Tyskland, Kejseren hedder Wilhelm II. Kejser Wilhelm II er altsaa vor Konge og Kejser."

Denne Meddelelse gives flere Steder i Bogen, undertiden med den Tilføjelse: „Landet, hvorpaa vi træler, tilhører ham. Vi er altsaa paa tysk Grund og derfor tør. vi (!) synge en tysk Sang: Hoil dir im Sirgerkranz!" Tor $i$ er godt; Forfatteren har skyet Trangsudtrykket skal I. Hans betegnende Navn er Krichau.

Dog Lærebøgerne faar jo først deres rette Betydning ved den Aand, hvori Undervisningen drives. Danmark, der næsten aldrig nævnes i Lærebøgerne uden i Forbigaaende til Beskæmmelse, nævnes ikke heller i Timerne. Det er Læreren forbudt at tale Dansk til de danske Børn, selv om han er dansk.

Men Lærerne regeres desuden med Jernhaand.

Det vrimler af Bestemmelser (Verfiigungen), der holder dem i Ave. Uafbrudt forlanges der af SkoleInspektørerne Oplysninger om Lærernes politiske Synsmaade, ja disse opfordres til at passe paa hverandre. Der folges skarpt med, hvem Læreren omgaas, on han kender Danske, om han er med til Fest paa Kejserens Fødselsdag, om han er Medlem af tysk-patriotiske Foreninger 
eller ikke. Opfylder han ikke Forventningerne, saa forsættes han enten til en ringere Stilling $i$ en rent tysk Egn eller, hvis han ikke vil moltage en saadan Plads, afskediges han uden Pension.

Højst interessant er et Circulære allerede fa 1867 om Valgene: Det er bragt i Erfaring, at Lærer N. N. ved Valget af Valgmænd har stemt med de Danske ("det danske Parti“). Han modtager herved en foreløbig Advarsel. Stemmeafgivningen er ganske vist - bedder det videre en statsborgerlig Ret, hvis Udøvelse er sikret ved Forfatningen, og er sikret Læreren som alle Statsborgere. Men paa den anden Side har Statsembedsmændene Forpligtelser, de maa overholde, og dertil hører den, ikke at stemme med de statsfjendtlige Partier. Men et saadant er netop det danske Parti, altsaa...

I et Circulære af 12. April 1898 lægges særlig Væọt paat Lærernes Færd og Holdning udenfor Tjenesteu. I et andet slaas det fast, at de, niar de agter sig ud paa Rejse i deres Ferier, skal søge om Tilladelse dertil og melde, hvor de agter sig hen. Meningen hermed er selvfølgelig alene den at sikre sig imod deres Ferieophold i Danmark.

Saaledes er det efterhaanden lykkedes at faa næsten alle danske og dansksindede Lærere fortrængte.

Under disse Omstændigheder er det med en virkelig Tilfredsstillelse at man erfarer den Frugtesløshed, hvormed disse Germaniseringsbestræbelser hidtil har været slagne. Børnene bliver ikke gjorte til Prøjsere i Skolen, kan ikke gøres dertil; de forstaar ikke den tyske Undervisning, plaprer blot mekanisk op hvad de har lært udenad.

Trods Alt staar den danske Sag i Slesvig endnu godt. 


\section{V.}

Inidlertid, Kappestriden, der i vore Dage er blevell skarpere end nogensinde mellem de Enkelte paa Handeleus og Industriens Omraader, er ogsaa bleven bestandig skarpere Folk og Folk imellem. Er vi Danske færre i Tal, saa betyder det en Opfordring til forgget Opmarksomhed og Indprentning af, at hvert enkelt Individ er kostbart. I de store Lande gør det ikke meget, om nogle tusinde Individer gaar legemligt eller andeligt til Grunde. Her taales det kun daarligt, at den Enkelte er uvirksom og unyttig, daarligere endnu, at han er et fordærvet og skadeligt Væsen. Han er kostbar som en Perle.

Lige efter 1864 behøvedes ingen Anstrengelse for at fastholde hvad der var Dansk i Slesvig. De Dansksinitede trængte ikke til Grunde, hvorfor de skulde være Danske. Dansk var Fædrelandet og Modersmaalet. Danske var Minder, Sange og Sagn. Man ventede desuden snarlig Tilbagevenden til Danmark. Desværre valgte jo kun altfor Mange da at forblive danske Undersaatter og udelukkede sig derved fra de tyskborgerlige Rettigheder, blev stemmeretsløse og $\mathrm{i}$ det Hele vanskeligt stillede. Næsten et helt Slægtled er derved for os gaaet tabt.

Først drømte man, som bekendt, om Franskmændene som Befriere. Rundt om i Nordslesvig saa man Syner, Kolonner i røde Bukser i skumringen paa Vejene eller i Luften, og Bladet Fadrelandet indregistrerede troligt al denne Overtro, disse Syner, disse Bukser. Man troerle at se hvad man ønskede at se. Saa brast Haabet om Hjælp fra Frankrig, og uden meget Haab rettede man Blikket mod Tilsagnet i Pragfredens femte Paragraf. For en Snes Aar siden opgav Østerrig sin Ret til at kræve 
Tilsagnet opfyldt. Nye Slagtled voksede op, og med al sin Kraft kastede Prøjsen sig nu over denne Ungdoms Fortyskning. Jeg sagde: Prøjseren behøver ikke at være elskværdig. Han har desvarre nok at kunne rose sig af. Han kan rose sig af at have et af Verdens ypperste Kultursprog; han kan gjøre den Højde gjieldende, hvorpaa tysk Videnskab staar eller tysk Musik eller tysk Teknik, Handel og Industri, der er begyndt at slaa selv Englændernes af Marken, efter at have fortrængt Franskmændenes mange Steder paa Verdensmarkedet. Og hvad har ikke Prøjsen, det tyske Rige overhovedet, at rose sig af som Krigsmagt. De overvældende Sejre over Frankrig har fremtor noget givet en berettiget Selvfølelse. Hvad Indtryk maa ikke paa en Skoledrengs Fantasi blot to saadanne Tal gøre, som at ved Sedan overgav 108,000 Franskmænd sig og ved Metz 173,000!

Nu kom der altsaa det Tidspunkt, da Valget stilledes en opvoksende Befolkning mellem det ogsaa aandeligt at tilhøre et af Jordens største og mest oplyste Sprogsamfund, Fastlandets bedst rustede og mest sejrrige Krigsmagt, et stort Folk i stærkt Opsving, og det aandeligt at tilhøre os.

Hvad havde vi i Sammenligning at byde paa? Hvad havde vi eller kunde vi til Gengæld have at rose os af?

Det er saa tydeligt, at et Barn kan forstaa det. Vi kunde svare: „Det er sandt, at Tyskerne er stærke og kloge, mægtige og dygtige som faa. Men vi har ét Fortrin for dem, som vejer op. Vi er et frit Folk; de er det ikke. Vi har intet personligt Styre og ingen Militarisme. Vi er vore egne Herrer; vi har vor Frihed at byde paa, den, vi altid er rede til at dele med Andre." - Kan vi nu med Sandhed sige saadan? 
Det maa komme dertil, at vi kan sige det.

Og kan vi end ikke henvise til vor Historie, der mest er en Historie om Nedgang i Magt og Omfang, saa kan vi henpege til, hvorledes vi ved ihærdigt Arbejde har søgt at raade Bod paa Tabene, og til, hvad vi i Aandens Verden har ydet, ret meget for et saa lille Folk. Vi kan pege paa vort Sprog, der i Løbet af et Aarhundrede er blevet dyrket og udviklet med lige saa megen Iver som det tyske, og som ikke staar tilbage for det fremmede hverken i Brugbarhed eller i Skønhed. Først og fremmest maa vi da kæmpe for Bevarelsen af vort Sprog, dette vege og dog stærke Modersmaal med Versets Musik, med Prosaens friere og rigere Bølgeslag, med Velklangens Orgeltoner og Nattergaleslag og Lethedens Fugleflugt. Som der staar i Oehlenschlägers „Der er et yndigt Land": Vort Sprog er stærkt og blødt.

Paa det Spørgsmaal, hvad vi Danske har at sætte imod Tyskernes berettigede Selvros, har man vistnok tidligere gjort sig Svaret for let, idet man dels har lukket sine Øjne for Tyskernes virkelige og store Fortjenester, dels har udsmykket vor Historie med digterisk Frihed. En ældre Tids Danskhed betænkte sig ikke paa at godkende Historien i Ingemanns Romaner eller paa at forvanske Slaget den 2. April fra et Nederlag til en Sejr. Den ny Tids Mænd har et mange Gange vanskeligere Hverv. Vi maa i Stedet for tidligere Tiders selvglade Danskhed sætte en sandere og mere rgte. Vi kan ikke længere til Tyskerne sige: „De Danske er vor Herres Hjærtefolk, I er det ikke." Vi maa nøjes med at sige, og vi maa naa til at kumne sige: "Vort Folk er frit."

Og overfor de vvermægtige Prøjsere maa vi hævde: 
I kalder jer dẹt rpperste Kulturfolk - man kan i vore Dage ikke fremme Kulturen ved barbariske Midler.

I svulmer af Nationalitetsfolelse og I vil voldelig herove en anden Folkestamme dens Nitionalitet. I havder altsaa Nationalitetsprincipet for .Jert eget Vedlkommende og forningter det for et Nabofollss.

I klager i vilde Skyer, naar Russerne fortranger Jert Spron i (stersuprovinserne eller naar (zecheme bekæeniper det i Bohmen - men det, I stempler som Forbrydelse, naar det gores mod Jer i Dorpat eller l'ray, det er jo netop det, I daglig selv sver i Hadersler og Aabenraa.

I roser Jer i Jer Nationalsang af, at Jere Fæulre clinde for Friheden - og I selv, I lever for 'Tvangen.

Georg Brandes 